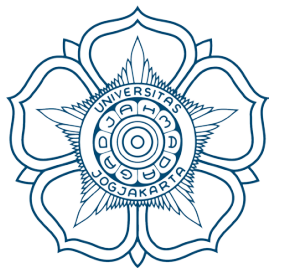
Judul Naskah : PERKEMBANGAN KONSEP ATAU PEMIKIRAN TEORITIK TENTANG DISKRESI BERBASIS PERCEPATAN INVESTASI DI DAERAH

Nama Penulis : Subadi dan Tiara Oliviarizky Toersina

MIMBAR HUKUM

$\begin{array}{ll}\text { DOI } & : \text { http://doi.org/10.22146/jmh.29222 } \\ \text { Penerbit } & : \text { Fakultas Hukum Universitas Gadjah Mada } \\ \text { URL } & : \text { jurnal.ugm.ac.id/jmh } \\ \text { E Issn } & : 2443-0994 \\ \text { P Issn } & : 0852-100 \mathrm{x}\end{array}$




\title{
PERKEMBANGAN KONSEP ATAU PEMIKIRAN TEORITIK TENTANG DISKRESI BERBASIS PERCEPATAN INVESTASI DI DAERAH
}

\author{
Subadi $^{*}$ dan Tiara Oliviarizky Toersina ${ }^{* *}$
}

\author{
Hukum Administrasi Negara Fakultas Hukum, Universitas Merdeka Madiun \\ Jl. Serayu No. 79 Madiun, Jawa Timur, 63137
}

\begin{abstract}
Regional autonomy as an effort to accelerate the welfare of the people still can not meet the expectations and still needed innovation or legal breakthrough by head of a district. This research has revealed that discretion can be a crucial and innovative solution to address the need, deadlock, legal vacuum, policies and regulations for accelerating investment in the region, with the obligation of reporting to the superior authority and not exceeding the limits of authority.
\end{abstract}

Keywords: concept, development, discretion, investment, region, theory.

\section{Intisari}

Otonomi daerah sebagai upaya mempercepat kesejahteraan rakyat masih belum dapat memenuhi harapan dan masih diperlukan inovasi atau terobosan-terobosan hukum oleh kepala daerah. Penelitian ini telah mengungkap dan menemukan bahwa diskresi dapat menjadi solusi kreaktif dan inovatif untuk mengatasi kebutuhan, kebuntuan, kekosongan hukum, kebijakan dan regulasi untuk percepatan investasi di daerah, dengan kewajiban melaporkan kepada atasannya dan tidak boleh melampaui batas kewenangan.

Kata Kunci: daerah, diskresi, investasi, konsep, perkembangan, teori.

\section{Pokok Muatan}

A. Pendahuluan 19

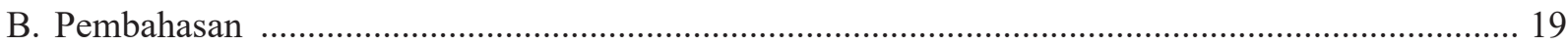

1. Perkembangan Konsep dan Pemikiran Teoritik tentang Diskresi .............................................. 19

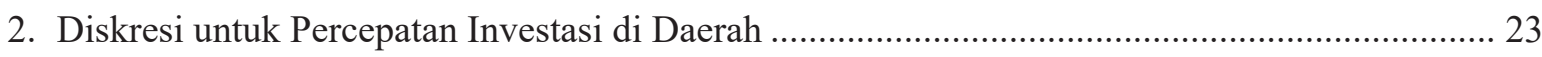

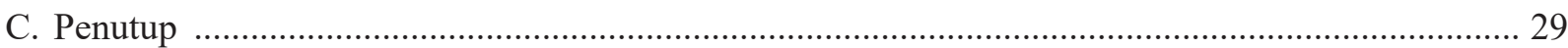

Alamat korespodensi: subadi@unmer-madiun.ac.id.

Alamat korespodensi: toersinatiara@unmer-madiun.ac.id. 


\section{A. Pendahuluan}

Otonomi daerah sebagai upaya mempercepat tercapainya kesejahteraan rakyat sudah berjalan hampir 20 (dua puluh) tahun dan dalam kenyataan masih jauh dari harapan. Pelaksanaan otonomi daerah atau desentralisasi seyogyanya memerlukan inovasi atau terobosan-terobosan cerdas oleh seorang kepala daerah. Namun dalam praktek kepala daerah sering mengalami kendala dan tidak bisa berbuat banyak karena peraturan belum atau tidak mengatur dengan tegas. Diskresi dapat menjadi salah satu solusi inovatif yang diharapkan mampu mengatasi kebutuhan, kebuntuan, kekosongan hukum, kebijakan dan regulasi yang belum atau tidak tegas. Diskresi dapat dikatakan sebagai suatu kebebasan yang diberikan kepada alat administrasi negara dengan mengutamakan keefektifan tercapainya suatu tujuan daripada berpegang teguh pada ketentuan hukum atau kewenangan yang sah untuk turut campur dalam melaksanakan tugastugas menyelenggarakan kepentingan umum.

Pelaksanaan otonomi daerah, pembangunan daerah otonom dan upaya percepatan tercapainya kesejahteraan rakyat perlu didukung dengan percepatan investasi di daerah. Kepala daerah harus diberikan kewenangan yang lebih luas yaitu diskresi dalam upaya mendatangkan investasi. Namun ternyata pelaksanaan diskresi untuk investasi di daerah (kabupaten/kota) masih banyak mengalami hambatan atau di beberapa daerah masih berjalan di tempat. Beberapa kepala daerah tidak atau belum berani menerima investasi yang masuk dengan alasan aturan tidak atau belum jelas.

Adanya tugas pemerintah yang semakin berat disertai semakin heterogennya permasalahan sosial memerlukan terobosan dan inovasi dari pemerintah. Secara teoritis, salah satu upaya untuk menjaga fiskal adalah dengan meningkatkan nilai investasi yang masuk ke dalam suatu negara atau daerah. Pada era otonomi daerah, daerah diberikan keleluasaan untuk merancang strategi percepatan investasi di daerahnya masing-masing. Percepatan investasi di suatu daerah akan berbanding lurus dengan tingginya pendapatan asli daerah (PAD) yang dapat dihasilkan dalam satu kurun waktu tertentu. Tingginya PAD akan menciptakan situasi pembangunan yang kondusif dan dinamis. Pembangunan tersebut menjadi alat untuk menciptakan dan/atau mempercepat tercapainya kesejahteraan dan kemakmuran masyarakat.

Perkembangan terbaru, pemerintah bersama Dewan Perwakilan Rakyat telah menerbitkan satu produk hukum tentang Administrasi Pemerintahan yang di dalamnya mengatur diskresi oleh pejabat administrasi pemerintahan. Produk hukum tersebut adalah Undang-Undang Nomor 30 Tahun 2014 tentang Administrasi Pemerintahan yang disahkan dan diundangkan pada tanggal 17 Oktober 2014. Terbitnya Undang-Undang tersebut, diharapkan akan menjadi payung hukum yang kuat bagi pejabat administrasi pemerintahan yang pada waktu tertentu harus menerbitkan terobosan hukum yang memiliki landasan hukum yang kuat agar tidak menyalahi atau tidak melanggar peraturan perundang-undangan (yuridis legal formal).

Berdasarkan atas uraian tersebut di atas, terdapat 2 (dua) permasalahan yang akan dibahas, yaitu; 1) perkembangan konsep dan pemikiran teoritik tentang diskresi; dan 2) diskresi untuk percepatan investasi di daerah.

\section{B. Pembahasan}

\section{Perkembangan Konsep dan Pemikiran Teoritik tentang Diskresi}

Diskresi secara umum dapat dimaknai kebebasan mengambil keputusan dalam setiap situasi yang dihadapi menurut pendapatnya sendiri sedangkan secara singkat diskresi pemerintah merupakan kekuasaan yang timbul karena perkembangan atau perluasan konsep fungsi pemerintahan. Diskresi dapat pula dimaknai sebagai kebebasan bertindak pemerintah untuk menjawab perkembangan tuntutan pemerintah sebagai penyelenggara kepentingan umum di dalam sebuah negara. Kebebasan bertindak pada pemerintah lahir karena situasi keterbatasan pengaturan hukum yang disebabkan kaidah kabur, kekosongan pengaturan atau kontradiksi dalam pengaturan. Sementara 
itu, dengan kondisi tersebut penyelenggaraan negara harus terus berjalan sehingga tidak dapat diberhentikan karena alasan-alasan diatas. Mencermati konsep sederhana tersebut, diskresi merupakan kekuasaan yang mengandung pengertian yang sangat spesifik yaitu pengecualian bagi situasi normal yang menyediakan pengaturan hukum memadai bagi pemerintah untuk bertindak. Pada situasi normal, kekuasaan yang berlaku bagi pemerintah adalah kekuasaan atau kewenangan terikat yang artinya dalam situasi tersebut asas legalitas yang merupakan bagian dari the rule of law akan selalu menjadi panglima.

Beberapa pakar hukum mengemukakan pandangan teoritik atau konsep tentang diskresi, di antaranya:

a. S. Prajudi Atmosudirjo yang mendefinisikan diskresi, discretion (Inggris), discretionair (Perancis), freies ermessen (Jerman) sebagai berikut :

Diskresi adalah kebebasan bertindak atau mengambil keputusan dari para pejabat administrasi negara yang berwenang dan berwajib menurut pendapat sendiri. Selanjutnya dijelaskan bahwa diskresi diperlukan sebagai pelengkap dari asas legalitas, yaitu asas hukum yang menyatakan bahwa "setiap tindakan hukum yang menyatakan bahwa setiap tindak atau perbuatan administrasi negara harus berdasarkan ketentuan undangundang". Namun demikian, tidak mungkin bagi undang-undang untuk mengatur segala macam kasus posisi dalam praktek kehidupan sehari-hari. ${ }^{1}$

b. Indroharto menyebut wewenang diskresi sebagai wewenang fakultatif, yaituwewenang yang tidakmewajibkan badan atau pejabat tata usaha negara menerapkan wewenangnya, tetapi memberikan pilihan sekalipun hanya dalam hal-hal tertentu sebagaimana ditentukan dalam peraturan dasarnya. ${ }^{2}$

c. Sjachran Basah menjelaskan bahwa freies ermessen adalah kebebasan untuk bertindak atas inisiatif sendiri akan tetapi dalam pelaksanaannya haruslah sesuai dengan hukum, sebagaimana telah ditetapkan dalam negara hukum berdasarkan Pancasila. ${ }^{3}$

d. Diana Halim Koentjoro mengartikan freies ermessen sebagai kemerdekaan bertindak administrasi negara atau pemerintah (eksekutif) untuk menyelesaikan masalah yang timbul dalam keadaan kegentingan yang memaksa saat peraturan penyelesaian untuk masalah itu belum ada. ${ }^{4}$

e. Esmi Warassih mengatakan bahwa dalam rangka pelaksanaan kebijaksanaan publik, para birokrat dapat menentukan kebijaksanaannya sendiri untuk menyesuaikan dengan situasi dimana birokrat itu berada terutama di dalam mengimplementasikan suatu kebijaksanaan publik. ${ }^{5}$ Adanya diskresi diharapkan agar dengan kondisi yang ada dapat dicapai suatu hasil atau tujuan yang maksimal.

Berdasarkan konsep, pemikiran teoritik dan atau doktrin-doktrin hukum tersebut di atas, maka dapat disimpulkan bahwa pada hakekatnya diskresi merupakan kebebasan bertindak atau kebebasan mengambil keputusan dari badan atau pejabat administrasi pemerintahan menurut pendapatnya sendiri sebagai pelengkap dari asas legalitas manakala hukum yang berlaku tidak mampu menyelesaikan permasalahan tertentu yang muncul secara tiba-tiba, yang disebabkan

\footnotetext{
S. Prajudi Atmosudirjo, 1994, Hukum Administrasi Negara, Ghalia Indonesia, Jakarta, hlm. 82.

Indroharto, 1993, Usaha Memahami Undang-Undang Tentang Peradilan Tata Usaha Negara, Pustaka Sinar Harapan, Jakarta, hlm. 99-101.

Sjachran Basah, 1997, Eksistensi dan Tolok Ukur Badan Peradilan Administrasi di Indonesia, Alumni, Bandung, hlm. 3.

Diana Halim Koentjoro, 2004, Hukum Administrasi Negara, Ghalia Indonesia, Bogor, hlm. 41.

Esmi Warassih Puji Rahayu, 2005, Pranata Hukum Sebuah Telaah Sosiologis, Suryandaru Utama, Semarang, hlm.138-139.
} 
karena peraturannya memang tidak ada atau karena peraturan yang ada yang mengatur tentang sesuatu hal tidak atau kurang jelas.

Mencermati beberapa konsep atau pandangan tersebut, maka dapat disimpulkan pula bahwa yang diperlukan adalah adanya kebebasan atau diskresi administrasi negara yang terdiri atas diskresi bebas dan diskresi terikat. Pada diskresi bebas undangundang hanya menetapkan batas-batas dan pejabat administrasi negara bebas mengambil keputusan apa saja asalkan tidak melampaui/melanggar batasbatas tersebut, sedangkan pada diskresi terikat, undang-undang menetapkan bebarapa alternatif keputusan dan administrasi negara bebas memilih salah satu alternatif keputusan yang disediakan oleh undang-undang.

Khusus dalam hubungannya dengan asas legalitas (legaliteitsbeginsel) yang dikenal dalam hukum pidana dan hukum Islam, namun asas legalitas yang dimaksud dalam tulisan ini adalah konteks hukum administrasi, yakni het beginsel van wetmatigheid van bestuur atau asas keabsahan dalam pemerintahan. Asas legalitas ini dianggap sebagai dasar terpenting dari negara hukum (al seen van belangrijkste fundamentenvan de rechtsstaat) dan mengandung arti bahwa pemerintah hanya dapat melakukan tindakan berdasarkan kewenangan yang diberikan dan dibatasi oleh undang-undang, "het bestuur kan allen op basis van door de wet toegekende en afgebakende bovoegdheden handelen". Meskipun asas legalitas itu dianggap sebagai prinsip terpenting dari negara hukum, namun mendasarkan setiap tindakan pemerintahan dibidang publik pada asas legalitas atau hukum tertulis sebenarnya hal tersebut bukan tanpa masalah. Hal ini menurut Bagir Manan disebabkan karena adanya cacat bawaan (natural defect) dan cacat buatan (artificial defect) dari peraturan perundang-undangan sebagai suatu bentuk hukum tertulis ${ }^{6}$.
Pemerintah telah melengkapi dirinya dengan kewenangan-kewenangan baik yang bersifat atributif maupun yang bersifat delegatif dalam kerangka menjalankan tugas pemerintahan. Dengan adanya perkembangan masyarakat, maka seringkali terdapat keadaan-keadaan tertentu yang sifatnya mendesak yang membuat pejabat/badan administrasi pemerintahan tidak dapat menggunakan kewenangannya, khususnya kewenangan yang bersifat terikat (gebonden bovegheid) dalam melakukan tindakan hukum dan tindakan faktual secara normal ${ }^{7}$

Marcus Lukman menjelaskan, bahwa persoalan-persoalan penting yang mendesak, sekurang-kurangnya mengandung unsur-unsur sebagai berikut:

a. Persoalan-persoalan yang muncul harus menyangkut kepentingan umum, yaitu kepentingan bangsa dan negara, kepentingan masyarakat luas, kepentingan rakyat banyak/bersama, serta kegiatan pembangunan.

b. Munculnya persoalan tersebut secara tiba-tiba, berada diluar rencana yang telah ditentukan.

c. Untuk menyelesaikan persoalan tersebut, peraturan perundangundangan belum mengatur atau hanya mengatur secara umum, sehingga administrasi negara mempunyai kebebasan untuk menyelesaikan atas inisiatifnya sendiri.

d. Prosedurnya tidak dapat diselesaikan menurut administrasi yang normal atau jika diselesaikan menurut prosedur administrasi yang normal justru kurang berdaya guna dan berhasil guna. ${ }^{8}$

Bertitik tolak dari kewenangan diskresi ini berarti bahwa sebagian kekuasaan yang dipegang oleh badan pembentuk undang-undang dipindahkan ke tangan pemerintah/administrasi negara sebagai badan eksekutif. Jadi, supremasi hukum badan legislatif diganti oleh supremasi badan eksekutif, karena administrasi negara melakukan penyelesaian

Bagir Manan dan Kuntana Magnar, 1987, Peranan Peraturan Perundang-undangan dalam Pembinaan Hukum Nasional, Armico, Bandung, hlm. 45 .

Julista Mustama, "Diskresi dan Tanggungjawab Administrasi Pemerintahan", https://ejournal.unpatti.ac.id, diakses pada 11 Mei 2017. Marcus Lukman, 1996, Eksistensi Peraturan Kebijaksanaan dalam bidang Perencanaan dan Pelaksanaan Rencana Pembangunan di Daerah serta Dampaknya Terhadap Pembangunan Materi Hukum Tertulis Nasional, Disertasi, Universitas Padjajaran, Bandung, hlm. 203. 
masalah tanpa harus menunggu perubahan undangundang dari bidang legislatif. Hal tersebut karena pada prinsipnya badan/pejabat administrasi pemerintahan tidak boleh menolak untuk memberikan pelayanan kepada masyarakat dengan alasan hukumnya tidak ada ataupun hukumnya ada tetapi tidak jelas, sepanjang hal tersebut masih menjadi kewenangannya.

Peraturan perundang-undangan mempunyai jangkauan yang terbatas sekedar moment opname dari unsur-unsur politik, ekonomi, sosial, budaya dan hankam yang paling berpengaruh pada saat pembentukan. Oleh karena itu peraturan perundangundangan akan tertinggal bila dibandingkan dengan perubahan masyarakat yang semakin cepat atau dipercepat. Selain itu, hal lain yang kerap menimbulkan masalah dalam penerapan asas legalitas adalah struktur norma hukum publik yang akan dijadikan dasar bagi tindakan pemerintahan. Berbeda dengan struktur norma hukum pidana atau perdata, struktur norma hukum publik khususnya hukum administrasi memiliki sifat berantai dan bertingkat. Artinya terhadap suatu urusan pemerintahan normanya tidak hanya terdapat dalam suatu undang-undang atau peraturan daerah tetapi bertebaran dalam berbagai peraturan perundangundangan. Dengan demikian, seorang pejabat yang akan melakukan tindakan hukum tertentu dituntut untuk mengkaji semua peraturan perundangundangan terkait. Hal ini merupakan keterbatasan tersendiri.

Adanya diskresi difungsikan untuk mengatasi keterbatasan pejabat memahami semua peraturan perundang-undangan terkait di bidang hukum administrasi. Dalam hal ini, freies ermessen atau diskresi, yakni kemerdekaan pemerintah untuk dapat bertindak atas inisiatif sendiri dalam menyelesaikan persoalan-persoalan sosial diperlukan. ${ }^{9}$ Dengan kata lain, freies ermessen merupakan salah satu sarana yang memberikan ruang bergerak bagi pejabat atau badan-badan administrasi negara untuk melakukan tindakan tanpa harus terikat sepenuhnya pada undang-undang. ${ }^{10}$

Patut diketahui, bahwa freies ermessen atau diskresi ini jika dituangkan dalam bentuk tertulis akan berubah menjadi peraturan kebijakan, yakni peraturan umum yang dikeluarkan oleh instansi pemerintahan berkenaan dengan pelaksanaan wewenang pemerintahan terhadap warga negara atau terhadap instansi pemerintahan lainnya yang dibuat tanpa dasar hukum tegas dalam UndangUndang Dasar dan undang-undang formal baik langsung maupun tidak langsung. Undang-Undang Nomor 30 Tahun 2014 tentang Administrasi Pemerintahan (selanjutnya disebut UU No. 30 Tahun 2014), memberi batasan terhadap diskresi dengan menyebutkan bahwa pejabat pemerintahan dan atau badan hukum lainnya yang menggunakan diskresi dalam mengambil keputusan wajib mempertimbangkan tujuan diskresi, peraturan perundang-undangan yang menjadi dasar diskresi dan asas-asas umum pemerintahan yang baik. ${ }^{11}$ Selanjutnya Pasal 28 ayat (2) dan ayat (3), menyebutkan, bahwa penggunaan diskresi wajib dipertanggungjawabkan kepada pejabat atasannya dan masyarakat yang dirugikan akibat keputusan diskresi yang telah diambil serta dapat diuji melalui upaya administratif atau gugatan di Peradilan Tata Usaha Negara.

Ketentuan tersebut berarti bahwa rancangan undang-undang administrasi pemerintahan bukan hanyaakanmemberibatas-batas penggunaan diskresi oleh badan/pejabat administrasi pemerintah akan tetapi juga mengatur mengenai pertanggungjawaban badan/pejabat administrasi pemerintahan terhadap penggunaan diskresi yang tidak hanya bersifat pasif dalam arti menunggu adanya gugatan dari masyarakat melalui Pengadilan Tata Usaha Negara akan tetapi juga bersifat aktif dengan adanya kewajiban mempertanggungjawabkan penggunaan

\footnotetext{
E. Utrecht, 1988, Pengantar Hukum Administrasi Negara Indonesia, Pustaka Tinta Mas, Surabaya,hlm. 30.

Marcus Lukman, Op.cit., hlm. 205.

Pasal 24 Undang-Undang Nomor 30 Tahun 2014 tentang Administrasi Pemerintahan (Lembaran Negara Republik Indonesia Tahun 2014 Nomor 292, Tambahan Lembaran Negara Republik Indonesia Nomor 5601).
} 
diskresi kepada pejabat atasannya mengingat hal tersebut merupakan suatu kewajiban yang sifatnya melekat pada kewenangan yang menjadi dasar adanya diskresi itu sendiri. Namun demikian, hal yang disayangkan adalah tidak ada sanksi jika pejabat administrasi pemerintahan tidak melaporkan tindakan diskresinya kepada atasan berdasarkan Pasal 28 ayat (2) dan (3) UU No. 30 Tahun 2014. Ketiadaan sanksi tersebut dapat menyebabkan pejabat administrasi pemerintahan yang menerbitkan keputusan diskresi berdalih bahwa keputusan yang diambilnya bukan keputusan diskresi ataupun berdalih tidak tahu bahwa keputusan yang diambilnya adalah keputusan diskresi. Walaupun demikian paling tidak dengan akan dijadikannya batas-batas penggunaan diskresi sebagai suatu norma yang mengikat, maka hal tersebut sudah cukup untuk menghindari dilaksanakannya penyalahgunaan wewenang (detournement de pouvoir) dan perbuatan sewenang-wenang (willekeur) oleh badan/pejabat administrasi pemerintahan sebab tujuan utama dari normatifikasi adalah menciptakan dan menjadikan Hukum Administrasi Negara yang menunjang kepastian hukum bagi warga Negara.

Menurut Anna Erliyana, penggunaan freies ermessen oleh Badan atau Pejabat administrasi Negara dimaksudkan untuk menyelesaikan persoalan-persoalan penting, mendesak serta tibatiba yang sifatnya kumulatif. ${ }^{12}$ Dalam kasus ini, ada kemungkinan muncul persoalan yang penting tetapi tidak mendesak untuk segera diselesaikan, ada pula kemungkinan muncul persoalan mendesak tetapi tidak terlalu penting untuk diselesaikan. Suatu persoalan baru dapat dikualifikasi sebagai persoalan penting apabila persoalan tersebut menyangkut kepentingan umum, sedangkan kriteria kepentingan umum harus ditetapkan oleh suatu peraturan perundang-undangan. ${ }^{13}$
Berdasarkan hal tersebut di atas dapat disimpulkan bahwa penggunaan kewenangan diskresi oleh Badan atau Pejabat administrasi pemerintahan hanya dapat dilakukan dalam hal tertentu dimana peraturan perundang-undangan yang berlaku tidak mengaturnya atau karena peraturan yang ada yang mengatur tentang sesuatu hal tidak jelas dan hal tersebut dilakukan dalam keadaan darurat atau mendesak demi kepentingan umum yang telah ditetapkan dalam suatu peraturan perundang-undangan.

\section{Diskresi untuk Percepatan Investasi di Daerah}

Upaya percepatan pembangunan, pengembangan atau pemberdayaan masyarakat harus didukung dengan percepatan investasi di daerah. Namun demikian, sebelum membahas hal tersebut lebih dalam maka perlu dijelaskan perkembangan konsep dan pemikiran teoriktik tentang investasi.

Para ahli tentu memiliki pandangan yang berbeda-beda mengenai konsep teoritis tentang investasi. Fitzgeral mengartikan investasi adalah aktivitas yang berkaitan dengan usaha penarikan sumber-sumber (dana) yang dipakai untuk mengadakan barang modal pada saat sekarang dan dengan barang modal akan dihasilkan aliran produk baru di masa yang akan datang. ${ }^{14}$ Investasi dikonstruksikan sebagai sebuah kegiatan untuk; 1) Penarikan sumber dana yang digunakan untuk pembelian barang modal; dan 2) Barang modal itu akan dihasilkan produk baru. ${ }^{15}$

Konsep atau pemikiran lain tentang investasi dikemukakan oleh Kamaruddin Ahmad yaitu kegiatan menempatkan uang atau dana dengan harapan untuk memperoleh tambahan atau keuntungan tertentu atas uang atau dana tersebut. ${ }^{16}$ Berdasarkan definisi ini, investasi difokuskan pada

\footnotetext{
12 Anna Erliyana, 2005, Hukum Administrasi Negara, Badan Penerbit Fakultas Hukum Universitas Indonesia, Jakarta, hlm. 138.

3 Ibid.

14 Fitzgeral sebagaimana dikutip oleh Salim H. S dan Budi Sutrisno, 2008, Hukum Investasi di Indonesia, Raja Grafindo Persada, Jakarta, hlm. 31. 
penempatan uang atau dana yang bertujuan untuk memperoleh keuntungan. Hal ini erat kaitannya dengan penanaman investasi di bidang pasar modal.

Pada Ensiklopedia Indonesia, investasi diartikan sebagai penanaman uang atau modal dalam proses produksi (dengan pembelian gedung, permesinan, bahan cadangan, penyelenggaraan uang kas serta perkembangannya). Dengan demikian cadangan modal diperbesar sejauh tidak ada modal barang yang harus diganti. Hakikat investasi dalam definisi ini adalah penanaman modal untuk proses produksi. Ini berarti bahwa investasi yang ditanamkan hanya untuk proses produksi sematamata, padahal dalam kegiatan investasi tidak hanya ditujukan untuk kegiatan produksi semata-mata, tetapi juga kegiatan untuk membangun berbagai sarana dan prasarana yang menunjang kegiatan investasi.

Komaruddin memberikan pengertian investasi dalam tiga artian, yaitu:

a. Suatu tindakan untuk membeli saham, obligasi atau suatu penyertaan lainnya;

b. Suatu tindakan membeli barangbarang modal;

c. Pemanfaatan dana yang tersedia untuk produksi dengan pendapatan di masa yang akan datang. ${ }^{17}$

Investasi dalam definisi ini dikonstruksikan sebagai tindakan membeli saham, obligasi dan barang-barang modal. Ini erat kaitannya dengan pembelian saham pada pasar modal, padahal penanaman investasi tidak hanya di pasar modal, tetapi juga di bidang lainnya seperti misalnya di bidang pariwisata, pertambangan minyak dan gas bumi, pertambangan umum, kehuatanan, pertanian, pelabuhan dan lain-lain. Jadi dapat disimpulkan bahwa yang diartikan investasi adalah penanaman modal yang dilakukan oleh investor baik investor asing maupun domestik dalam berbagai bidang usaha yang terbuka untuk investasi, dengan tujuan untuk memperoleh keuntungan. ${ }^{18}$

Pemerintah terus melakukan berbagai upaya dalam meningkatkan arus investasi ke Indonesia. Upaya tersebut antara lain dengan pendelegasian kewenangan pengelolaan investasi kepada pemerintah daerah. Sayangnya, pendelegasian kewenangan tersebut belum sepenuhnya berjalan karena pembagian pengelolaan investasi belum tertata dengan cermat. Oleh karena itu hal ini menimbulkan kesan bahwa pemerintah pusat belum sepenuhnya mendelegasikan wewenang (desentralisasi) ke pemerintah daerah dalam urusan investasi. ${ }^{19}$

Pemerintah pusat, provinsi dan kabupaten/ kota mempunyai peranan yang sangat penting dalam meningkatkan pelaksanaan investasi di Indonesia. Pasal 30 Undang-Undang Nomor 25 Tahun 2007 tentang Penanaman Modal menyatakan bahwa pelaksanaan investasi merupakan kewenangan pemerintah, pemerintah provinsi dan kabupaten $/$ kota. ${ }^{20}$ Kewenangan pemerintah adalah hak dan kekuasaan pemerintah untuk menentukan atau mengambil kebijakan dalam rangka penyelenggaraan pemerintahan. ${ }^{21}$

Pada dasarnya kewajiban pemerintah daerah adalah menjamin kepastian dan keamanan berusaha bagi pelaksanaan penanaman modal. ${ }^{22}$ Namun demikian, perlu diatur kewenangan pemerintah kabupaten/kota dalam penyelenggaraan investasi untuk menjamin kepastian dan keamanan. Penyelenggaraan penanaman modal yang ruang lingkupnya lintas kabupaten/kota menjadi urusan

\footnotetext{
Salim H.S. dan Budi Sutrisno, Op.cit., hlm. 32.

Secara garis besar, investasi dibagi dua macam yaitu investasi asing dan domestik. Investasi asing merupakan investasi yang bersumber dari pembiayaan luar negeri. Sementara itu, investasi domestik merupakan investasi yang bersumber dari pembiayaan dalam negeri.

Sentosa Sembiring, 2007, Hukum Investasi, CV. Nuansa Aulia, Bandung, hlm. 92-93.

20 Lebih lengkap lihat Pasal 30 Undang-Undang Nomor 25 Tahun 2007 tentang Penanaman Modal (Lembaran Negara Republik Indonesia Tahun 2007 Nomor 67, Tambahan Lembaran Negara Republik Indonesia Nomor 4724).

21 Pasal 1 angka 3 Peraturan Pemerintah Nomor 25 Tahun 2000 tentang Kewenangan Pemerintah dan Kewenangan Provinsi sebagai Daerah Otonom (Lembaran Negara Republik Indonesia Tahun 2000 Nomor 54, Tambahan Lembaran Negara Republik Indonesia Nomor 3952)

22 Pasal 30 ayat (1) Undang-Undang Nomor 25 Tahun 2007 tentang Penanaman Modal (Lembaran Negara Republik Indonesia Tahun 2007 Nomor 67, Tambahan Lembaran Negara Republik Indonesia Nomor 4724).
} 
pemerintah provinsi. $^{23}$ Kewenangan provinsi sebagai daerah otonom dalam bidang penanaman modal adalah: Pertama, pelayanan administrasi penanaman modal termasuk lintas kabupaten/kota. Kedua, melakukan kerjasama dengan kabupaten/ kota. $^{24}$

Penyelenggaraan penanaman modal yang ruang lingkupnya berada dalam satu kabupaten/ kota menjadi urusan pemerintah kabupaten/kota. ${ }^{25}$ Dalam Keputusan Menteri Dalam Negeri Nomor 130-67 Tahun 2002 tentang Pengakuan Kewenangan Kabupaten dan Kota di bidang penanaman modal telah ditentukan lima macam kebijakan. Kelima macam kebijakan itu sebagai berikut: ${ }^{26}$

Pertama, kebijakan dan perencanaan pengembangan penanaman modal meliputi: identifikasi potensi sumber daya daerah kabupaten/kota yang hasilnya disajikan dalam bentuk peta investasi daerah kabupaten/ kota dan petunjuk (direktori) tentang potensi sumber daya alam, sumber daya manusia serta kelembagaan; identifikasi dan penyusunan daftar pengusaha kecil, menengah dan besar untuk calon mitra usaha termasuk dalam rangka kemitraan; penyusunan program pengembangan penanaman modal daerah kabupaten/kota dalam bentuk Rencana Strategis Daerah (Renstrada) sesuai dengan Program Pembangunan Daerah (Propeda) kabupaten/kota; penetapan bidang usaha unggulan/prioritas sesuai dengan potensi dan daya dukung daerah kabupaten/kota dalam bentuk Daftar Bidang-Bidang Usaha Unggulan/Prioritas; penyiapan usulan bidang-bidang usaha yang tertutup mutlak untuk penanaman modal, tertutup untuk PMA dan bidang-bidang usaha unggulan/ prioritas; penyusunan profil-profil proyek penanaman modal bidang-bidang usaha unggulan/prioritas; penyusunan profil-profil investasi proyek kemitraan; penetapan kebijakan pemberian insentif khusus sesuai dengan kewenangan daerah kabupaten/ kota; pelaksanaan pelatihan dan penyuluhan teknis dan bisnis bagi usaha kecil menengah; penyelenggaraan kewenangan lain di bidang kebijakan dan perencanaan pengembangan penanamam modal yang belum ditetapkan sepanjang tidak bertentangan dengan kebijakan pemerintah pusat dan provinsi. Kedua, promosi dan kerjasama internasional penanaman modal meliputi : penyelenggaraan promosi penanaman modal daerah baik di dalam maupun di luar negeri, seperti seminar, pameran, temu usaha dan lokakarya; pembuatan bahan promosi penanaman modal daerah dalam bentuk media cetak, antara lain daftar peluang usaha dan profil proyek unggulan/prioritas, profil pengusaha daerah yang potensial untuk bermitra, prosedur penanaman modal dan dalam bentuk media elektronik, antara lain : film, video, slide, CD ROM, dan multimedia/situs web; kerjasama dengan provinsi dan pemerintah pusat (BKPM) dalam penyelenggaraan promosi penanaman modal daerah; pelaksanaan forum temu usaha dan penjodohan bagi usaha kecil dan menengah dengan usaha besar dalam rangka kemitraan; kerja sama dengan pihak ketiga dalam rangka penyelenggaraan promosi penanaman modal daerah baik di dalam maupun di luar negeri; pengiriman misi penanaman modal ke daerah lain dan ke lau negeri; penerimaan misi penanaman modal dari daerah lain dan dari luar negeri; pelaksanaan kerja sama luar negeri sepanjang tidak bertentangan dengan kebijakan pemerintah pusat; penyiapan materi perjanjian dalam rangka kerjasama sub regional di bidang penanaman modal seperti kerja sama Indonesia-Malaysia-Singapore Growth Triangle (IMS-GT), Indonesia-MalaysiaThailand Growth Triangle (IMT-GT), Brunei Darussalam-Indonesia-MalaysiaPhilipinnes East ASEAN Growth Area (BIMPEAGA) dan Austalia-Indonesia Development Area (AIDA); pelaksanaan sosialisasi atas perjanjian kerja sama luar negeri di bidang penanaman modal kepada aparatur dan dunia usaha; penyelenggaraan kewenangan lain di bidang lain di bidang promosi dan kerjasama internasional penanaman modal yang belum ditetapkan sepanjang tidak bertentangan

\footnotetext{
23 Pasal 30 ayat (5) Undang-Undang Nomor 25 Tahun 2007 tentang Penanaman Modal (Lembaran Negara Republik Indonesia Tahun 2007 Nomor 67, Tambahan Lembaran Negara Republik Indonesia Nomor 4724).

24 Salim H.S. dan Budi Sutrisno, Op.cit., hlm. 91.

25 Pasal 30 ayat (6) Undang-Undang Nomor 25 Tahun 2007 tentang Penanaman Modal (Lembaran Negara Republik Indonesia Tahun 2007 Nomor 67, Tambahan Lembaran Negara Republik Indonesia Nomor 4724).

26 Keputusan Menteri Dalam Negeri Nomor 130-67 Tahun 2002 tentang Pengakuan Kewenangan Kabupaten dan Kota.
} 
dengan kebijakan pemerintah pusat dan provinsi. Ketiga, pelayanan perizinan penanaman modal meliputi : pemberian persetujuan seluruh proyek baru dan perluasan PMDN atas bidang usaha/proyek selain yang menjadi kewenangan provinsi dan pusat; pemberian persetujuan perubahan rencana proyek PMDN atas persetujuan proyek; pemberian perizinan pelaksanaan persetujuan penanaman modal dalam rangka PMDN meliputi angka pengenal importer terbatas (APIT), izin memperkerjakan tenaga kerja warga negara asing (IKTA) berdasarkan visa untuk maksud kerja yang telah disetujui oleh instans yang berwenang di bidang keimigrasian, izin usaha tetap/izin usaha perluasan, izin lokasi, sertifikat hak-hak atas tanah, izin mendirikan bangunan (IMB), Izin Undang-Undang Gangguan/HO; pemberian insentif khusus penanaman modal yang menjadi kewenangannya; penyelenggaraan kewenangan lain di bidang pelayanan perizinan penanaman modal yang belum ditetapkan sepanjang tidak bertentangan dengan kebijakan pemerintah pusat dan provinsi. Keempat, pengendalian penanaman modal, meliputi: pemantauan perkembangan pelaksanaan seluruh penanaman modal yang berada di wilayahnya; pembinaan terhadap pelaksanaan seluruh penanaman modal dalam rangka peningkatan realisasi penanaman modal yang berada di wilayahnya; pengawasan terhadap pelaksanaan seluruh penanaman modal yang berada di wilayahnya; pemberian sanksi terhadap perusahaan yang melakukan pelanggaran atas ketentuan penanaman modal yang surat persetujuannya dikeluarkan kabupaten/kota; penyelesaian permasalahan yang dialami oleh perusahaan penanaman modal yang berada di wilayanya; penyusunan laporan perkembangan seluruh persetujuan dan realisasi penanaman modal di daerahnya secara berkala; penyelenggaraan kewenangan lain di bidang pengendalian penanaman modal yang belum ditetapkan sepanjang tidak bertentangan dengan kebijakan pemerintah pusat. Kelima, sistem informasi penanaman modal meliputi: pembangunan dan pengembangan sistem informasi penanaman modal yang terintegrasi dengan sistem informasi penanaman modal provinsi dan pemerintah pusat (BKPM); pengumpulan dan pengolahan data persetujuaan dan realisasi proyek PMDN dan PMA; pemutakhiran data dan informasi promosi penanaman modal daerah.

Peranan pemerintah daerah untuk menjalankan koordinasi sangat dibutuhkan antara pemerintah pusat dan pemerintah provinsi serta pemerintah daerah. Koordinasi tersebut dijalankan dengan kewenangan otonomi daerah yang telah diberi berdasarkan perundang-undangan. Investasi merupakan bagian integral dalam pengembangan potensi daerah. Oleh karena itu potensi daerah harus dapat menjadi sasaran bagi pengelolaan pendapatan asli daerah. Namun yang menjadi faktor-faktor penghambat adalah tidak adanya peraturan perundang-undangan yang jelas mengatur terhadap kepastian perlindungan hukum dalam melakukan kegiatan investasi di daerah, sehingga nampak jelas kebijakan daerah mewujudkan iklim yang baik tidak sesuai dengan prinsip otonomi investasi otonomi daerah. Keadaan ini pun menghambat masuknya investasi ke daerah. Seorang kepala daerah diberikan kewenangan untuk menetapkan kebijakan atau mengambil suatu tindakan yang diperlukan untuk dapat mengatasi permasalahan tersebut. Responsifitas kepala daerah ini jamak disebut dengan diskresi. Hal ini sangat penting mengingat permasalahan percepatan investasi merupakan permasalahan yang kompleks bersifat multisektoral dan saling terkait satu dengan yang lain.

Satu dekade terakhir, investasi tidak saja merupakan kebutuhan penting bagi suatu negara dalam pengembangan ekonomi, namun juga merupakan sarana utama dalam pengembangan suatu industri. Terutama dalam era ini, liberalisasi dan globalisasi ekonomi sudah melanda seluruh dunia, termasuk dalambidang investasi asing. ${ }^{27}$ Keberadaan investasi di suatu negara terkait dengan adanya tuntutan untuk menyelenggarakan pembangunan nasional di negara tersebut. Pada era masyarakat yang semakin terbuka seperti saat ini, kebebasan 
mendapatkan informasi publik semakin luas dan era kebebasan berpendapat menjadi semakin dijamin, maka pemerintah daerah harus mampu mempunyai solusi yang strategis agar kehidupan masyarakat semakin tertib dan semakin tertata termasuk juga permasalahan peningkatan pertumbuhan ekonomi di masyarakat. Arus informasi yang semakin lancar disertai tingkat pendidikan dan pengetahuan yang semakin meningkat memiliki implikasi positif bagi perkembangan tata pemerintahan dan sehingga pemerintah daerah dituntut untuk meningkatkan akuntabilitas, transparansi dan keterbukaan terhadap segala kebijakan yang dibuat. Hal ini berfungsi sebagai "control of social" yang berasal dari masyarakat sendiri dalam mengawasi jalanya pemerintahan tersebut.

Kebijakan yang telah dijamin secara legal yuridis dalam arti telah memiliki dasar hukum yang jelas dalam peraturan perundang-undangan yang ada tidak memiliki konsekuensi yuridis yang dikhawatirkan. Pada perjalanannya, seringkali kepala daerah dalam menjalankan kewenangannya dalam pemerintahan terbentur pada tidak diaturnya atau belum diaturnya urusan tersebut dalam ketentuan peraturan perundang-undangan yang ada. Hal ini tentunya menuntut kepala daerah untuk mengeluarkan suatu kebijakan yang dijadikan "terobosan" untuk mengatasi permasalahan yang ada di masyarakat tersebut. Secara teori, kepala daerah selaku pejabat pemerintahan memiliki kewenangan untuk menerbitkan kebijakan baik yang telah dijamin oleh peraturan perundangundangan maupun yang belum diatur.

Negara hukum (rechtstaat) dan negara kesejahteraan (welfare staat) saat ini dituntut untuk menjalankan sistem pemerintahan yang baik. Hal tersebut bertujuan agar terwujudnya kesejahteraan masyarakat. Dengan demikian, pemerintah dituntut untuk dapat menyelesaikan persoalan di segala aspek yang berkaitan dengan warga negaranya. Walaupun belum terdapat dasar aturan yang mengatur mengenai tindakan yang akan diambil oleh aparat penyelenggara pemerintahan hal tersebut tidak dapat dijadikan alasan. Atas dasar inilah pemerintah diberikan kebebasan untuk berbuat atau bertindak dengan inisatif sendiri (freies ermessen) untuk menyelesaikan segala persoalan atau permasalahan dalam penyelenggaraan pemerintahan guna memenuhi kepentingan umum.

Salah satu tujuan Indonesia dibentuk adalah bagaimana menyejahterakan masyarakatnya. Hal ini dapat dilihat dalam pembukaan Undang-Undang Dasar Negara Republik Indonesia (UUD 1945). Namun, patut disadari bahwa untuk mencapai tujuan tersebut mudah dan memerlukan kerja keras semua pihak. Salah satu sarana yang dapat dicapai dalam rangka memperoleh tujuan tersebut yakni melalui pranata pembangunan. Oleh karena itu perlu dicari sumber dana lain, yaitu penanaman modal atau investasi di daerah. Salah satu sumber modal yang dapat dimanfaatkan adalah melalui pranata hukum yang jelas dalam bidang penanaman modal. ${ }^{28}$

Otonomi daerah berimplikasi bebasnya pemerintah daerah secara otonom berhak untuk mengelola dan mengoptimalkan segala potensi yang ada di wilayahnya masing-masing. Dilihat dari sudut pandang ini, pemerintah daerah berpeluang besar untuk menarik calon investor masuk ke daerah. Di sisi lain bagi investor sendiri adanya kebijakan otonomi daerah bisa membandingkan daerah mana yang paling memberi peluang dalam melakukan investasi.

Beberapa faktor penghambat investasi di daerah dapat dijabarkan sebagai berikut :29

1. Pembenahan kebijakan dan implementasi investasi:

Hal yang terjadi adalah inkonsistensi dalam kebijakan, pengaturan dan implementasi investasi. Inkonsistensi dapat dilihat dari tugas dan fungsi pokok Badan Koordinasi Penanaman Modal (BKPM) apakah sebagai "one stop services center" atau sebagai badan promosi investasi. Hal ini

\footnotetext{
28 Hendrik Budi Untung, 2009, Hukum Investasi, Sinar Grafika, Jakarta, hlm.3.

29 Fu Handi, "Permasalahan Investasi di Indonesia", https://beritadaerah.co.id, diakses pada 2 Mei 2017.
} 
dapat membingungkan investor/calon investor.

2. Masalah dan hambatan birokrasi:

Sudah bukan rahasia umum rentang birokrasi di daerah yang terlalu panjang telah mengakibatkan biaya yang mahal serta terbuka peluang korupsi atau pungutan liar yang dapat mengakibatkan buruknya iklim investasi di Indonesia.

3. Ketidakpastian dalam interpretasi dan implementasi otonomi daerah:

Dengan banyaknya permasalahan terkait perda dibidang investasi menunjukkan bahwa pemahaman terhadap otonomi daerah masih keliru. Permasalahan dimaksud banyak terkait dengan masalah pajak dan retribusi daerah yang mengakibatkan kegiatan investasi menjadi unpredictable. Jika permasalahan ini terus berlanjut, maka daya saing investasi akan selalu menurun karena rendahnya minat investor untuk berinvestasi di daerah.

4. Sumberdayamanusiadanpermasalahan kebijakaan ketenagakerjaan:

Penerapan kebijakan di bidang ketenagakerjaan yang tidak transparan telah mengakibatkan kondisi ketenagakerjaan menjadi kurang produktif, tenaga kerja yang tidak terampil, etos kerja yang lemah, kenaikan upah minimum yang terlalu cepat, dan maraknya demo dan pemogokan serta kasus-kasus perburuhan yang membuat investor melakukan relokasi usahanya ke beberapa negara tetangga yang lebih kondusif. Tingkat pendidikan dan rendahnya kompetensi yang dimiliki sumber daya manusia telah menjadi salah satu pertimbangan investor untuk berinvestasi di daerah.

5. Tingkat korupsi yang masih tinggi:
Pelaksanaan otonomi daerah yang masih menunjukkan berbagai kelemahan bahkan makin merebakkan praktek korupsi dan pungutan liar ke daerah-daerah. Dalam praktek dilapangan banyak yang menggunakan instrumen regulasi sebagai justifikasinya.

6. Kurangnya insentif bidang pajak maupun non pajak:

Dalam implementasinya di daerah, skema insentif yang diatur dalam berbagai aturan ternyata tidak dilaksanakan sebagaimana mestinya, sehingga kebijakan investasi yang di tetapkan oleh pemerintah tidak sepenuhnya dapat dirasakan manfaatnya oleh investor.

7. Rendahnya jaminan dan perlindungan investasi:

Meskipun UU Penanaman modal telah mengatur jaminan dan perlindungan terhadap kegiatan investasi dan pemerintah secara aktif menyepakati berbagai perjanjian bilateral mengenai promosi dan perlindungan investasi, namun dalam prakteknya kurang terlihat komitmen yang sungguhsungguh dalam perlindungan investasi.

8. Lemahnya penegakan dan kepastian hukum:

Munculnya berbagai kasus seperti : kasus cemex, divestasi KPC, Karaha Bodas, Mining Churcil, dan lainnya menunjukkan bahwa penegakan hukum khususnya hukum kontrak masih lemah. Hal ini mengakibatkan ketidakpastian hukum dan pada akhirnya mengurangi daya saing Indonesia sebagai negara tujuan investasi.

9. Lemahnya koordinasi antar kelembagaan:

Ketidakjelasaan tugas pokok dan 
fungsi dari lembaga pemerintahan telah menimbulkan koordinasi yang tidak harmonis dalam konteks kegiatan investasi Masalah percepatan investasi di daerah masih sering terjadi tumpang tindih kewenangan antara pusat dan daerah, antara dinas dengan dinas, bahkan di daerah masih kerap terjadi saling lempar tanggung jawab antar dinas. Koordinasi yang kurang terjadi oleh adanya pertimbangan subyektif yang berlatar belakang kepentingan suatu kelompok (politis) maupun ekonomi.

Berdasarkan penjabaran berbagai hambatan dalam percepatan investasi tersebut, pemerintah daerah dalam hal ini termanifestasikan oleh kepala daerah dituntut untuk melakukan terobosan yang inovatif untuk dapat meningkatkan peluang investasi di daerahnya masing-masing. Hal ini mutlak dilakukan karena tingkat kompetisi antar daerah dalam hal meningkatkan nilai investasi terus meningkat dan untuk menunjang itu legalisasi diskresi dalam ketentuan peraturan perundangundangan kita memberikan atmosfer positif bagi kepala daerah untuk tidak takut lagi berkonsekuensi hukum ketika akan membuat suatu kebijakan terkait penunjang percepatan investasi di daerahnya.

\section{Penutup}

Berdasarkan uraian kemajuan penelitian tersebut di atas, dapat diambil kesimpulan, sebagai berikut:

1. Perkembangan konsep dan pemikiran teoritik tentang diskresi atau discretion (Inggris), discretionair (Perancis), freies ermessen (Jerman) sebagai kebebasan bertindak atau mengambil keputusan dari para pejabat administrasi negara yang berwenang dan berwajib menurut pendapat sendiri, dikresi diperlukan sebagai pelengkap dari asas legalitas. Diskresi sebagai wewenang fakultatif, yaitu; wewenang yang tidak mewajibkan badan atau pejabat tata usaha negara menerapkan wewenangnya, tetapi memberikan pilihan sekalipun hanya dalam hal-hal tertentu sebagaimana ditentukan dalam peraturan dasarnya. Konsep diskresi sebagai freies ermessen adalah kebebasan untuk bertindak atas inisiatif sendiri, akan tetapi dalam pelaksanaannya haruslah tindakan-tindakan administrasi negara itu sesuai dengan hukum, sebagaimana telah ditetapkan dalam negara hukum berdasarkan Pancasila. Konsep yang mempertajam mengartikan freies ermessen sebagai kemerdekaan bertindak administrasi negara atau pemerintah (eksekutif) untuk menyelesaikan masalah yang timbul dalam keadaan kegentingan yang memaksa, dimana peraturan penyelesaian untuk masalah itu belum ada. Persoalan-persoalan penting yang mendesak, sekurang-kurangnya mengandung unsur-unsur sebagai berikut: a) Persoalan-persoalan yang muncul harus menyangkut kepentingan umum, yaitu kepentingan bangsa dan negara, kepentingan masyarakat luas, kepentingan rakyat banyak/ bersama, serta kegiatan pembangunan; b) Munculnya persoalan tersebut secara tiba-tiba, berada diluar rencana yang telah ditentukan; c) Untuk menyelesaikan persoalan tersebut, peraturan perundang-undangan belum mengatur atau hanya mengatur secara umum, sehingga administrasi negara mempunyai kebebasan untuk penyelesaikan atas inisiatifnya sendiri; d) Prosedurnya tidak dapat diselesaikan menurut administrasi yang normal atau jika diselesaikan 
menurut prosedur administrasi yang normal justru kurang berdaya guna dan berhasil guna. Perkembangan pemikiran tentang diskresi dalam peraturan perundang-undangan telah diterbitkan Undang-Undang Nomor 30 Tahun 2014 tentang Administrasi Pemerintahan (UU No. 30 tahun 2014) yang mengatur ketentuan mengenai tanggung jawab pemerintah dalam sebuah peraturan perundang-undangan yang dapat dijadikan dasar pijakan atau landasan hukum bagi para kepala daerah atau pejabat administrasi pemerintahan dalam menjalankan pemerintahannya.

2. Diskresi untuk percepatan investasi di daerah, merupakan bagian integral dalam pengembangan atau pemberdayaan dan pendayagunaan potensi di daerah. Kewenangan penyelenggaraan penanaman modal atau investasi untuk ruang lingkupnya yang berada dalam satu kabupaten/kota menjadi urusan pemerintah kabupaten/ kota, sedangkan penyelenggaraan penanaman modal yang ruang lingkupnya lintas kabupaten/kota menjadi urusan pemerintah provinsi. Kewenangan provinsi sebagai daerah otonom dalam bidang penanaman modal, yaitu; a) Pelayanan administrasi penanaman modal termasuk lintas kabupaten/kota; b) dan melakukan kerjasama dengan kabupaten/kota. Namun upaya percepatan investasi di daerah masih banyak hambatan, yaitu; a) Pembenahan kebijakan, dan implementasi investasi; b) Masalah dan hambatan birokrasi; c) Ketidakpastian dalam interpretasi dan implementasi otonomi daerah; d) Sumber daya manusia dan permasalahan kebijakaan ketenagakerjaan; e) Tingkat korupsi yang masih tinggi; f) Kurangnya insentif bidang pajak maupun non pajak; g) Rendahnya jaminan dan perlindungan investasi; h) Lemahnya penegakan dan kepastian hukum; i) Lemahnya koordinasi antar kelembagaan.

\section{DAFTAR PUSTAKA}

\section{A. Buku}

Ahmad, Kamarudin,1996,Dasar-Dasar Manajemen Investasi, Rineka Cipta, Jakarta.

Arifin P. Soeria Atmadja, 2008, Keuangan Publik dalam Perspektif Huku, Teori, Kritik dan Praktik, Rajawali Press, Jakarta.

Atmosudirjo, S. Prajudi,1994, Hukum Administrasi Negara, Ghalia Indonesia; Jakarta.

Basah, Sjachran, 1997, Eksistensi dan Tolok Ukur Badan Peradilan Administrasi di Indonesia, Alumni, Bandung.

Erliyana, Anna, 2005, Hukum Administrasi Negara,

Badan Penerbit Fakultas Hukum Universitas Indonesia, Jakarta.
Prenamedia Group, Jakarta.

Indroharto, 1993, Usaha Memahami UndangUndang Tentang Peradilan Tata Usaha Negara, Pustaka Sinar Harapan, Jakarta.

Koentjoro, Diana Halim, 2004, Hukum Administrasi Negara, Ghalia Indonesia, Bogor.

Manan, Bagir dan Kuntana Magnar, 1987, Peranan

Peraturan Perundang-undangan dalam

Pembinaan Hukum Nasional, Armico, Bandung.

Rahayu, Esmi Warassih Puji,2005, Pranata Hukum Sebuah Telaah Sosiologis, Suryandaru Utama, Semarang.

Rakhmawati, Rosyidah, 2004, Hukum Penanaman 
Modal di Indonesia, Bayu Media, Malang.

Salim H.S. dan Budi Sutrisno, 2008, Hukum

Investasi di Indonesia, P.T. Raja Grafindo Persada, Jakarta.

Sembiring, Sentosa 2007, Hukum Investasi, CV. Nuansa Aulia, Bandung.

Untung, Hendrik Budi, 2009, Hukum Investasi, Sinar Grafika, Jakarta.

Utrecht, E., 1988, Pengantar Hukum Administrasi

Negara Indonesia, Pustaka Tinta Mas, Surabaya.

\section{B. Hasil Penelitian/Tugas Akhir}

Lukman, Marcus, 1996, Eksistensi Peraturan Kebijaksanaan dalam Bidang Perencanaan dan Pelaksanaan Rencana Pembangunan di Daerah serta Dampaknya terhadap Pembangunan Materi Hukum Tertulis Nasional, Disertasi, Universitas Padjajaran, Bandung.

\section{Peraturan Perundang-Undangan}

Undang-Undang Nomor 25 Tahun 2007 tentang Penanaman Modal (Lembaran Negara Republik Indonesia Tahun 2007 Nomor 67, Tambahan Lembaran Negara Republik Indonesia Nomor 4724).

Undang-Undang Nomor 30 Tahun 2014 tentang Administrasi Pemerintahan(Lembaran Negara Republik Indonesia Tahun 2014 Nomor 292, Tambahan Lembaran Negara Republik Indonesia Nomor 4724).

Peraturan Pemerintah Nomor 25 Tahun 2000 Tentang Kewenangan Pemerintah dan Kewenangan Provinsi Sebagai Daerah Otonom (Lembaran Negara Republik Indonesia Tahun 2000 Nomor 54, Tambahan Lembaran Negara Republik Indonesia Nomor 3952).

Keputusan Menteri Dalam Negeri Nomor 130-67 Tahun 2002 tentang Pengakuan Kewenangan Kabupaten dan Kota.

\section{Internet}

Handi, Fu, "Permasalahan Investasi di Indonesia", https://beritadaerah.co.id, diakses 2 Mei 2017.

Mustama, Julista, "Diskresi dan Tanggungjawab Administrasi Pemerintahan", https:// ejournal.unpatti.ac.id, diakses 11 Mei 2017. 